\title{
A two-year retrospective statistical analysis of trauma cases in our institute
}

\author{
Sateesh Kumar Muppasani ${ }^{*}$ Vijaya Durga Reddy \\ From International Summit on Emergency Medicine and Trauma 2014 \\ Puducherry, India. 12-16 February 2014
}

\section{Objective}

This is a retrospective study of trauma cases from January 2007-December 2009 (212 patients) to determine the incidence of gender, age, alcohol influence, mode of injury, time of injury, nature of injuries, hospital stay and to suggest preventive methods.

\section{Methods}

This is a retrospective study of trauma cases from January 2007-December 2009 (212 patients). After obtaining permission from the concerned authorities, a pre designed questionnaire was used to collect data from emergency department. the data being computerised and analysed.

\section{Results}

Road traffic accidents (RTA) were the common cause of morbidity and mortality in India. Among 212 trauma patients $79.70 \%$ were road traffic accidents, men sustained more injuries (84\%), mostly in the age group of 20-30 yrs (73\%). Most of them sustained fractures (50.47\%), and most of the accidents occurred during night time (58\%), afternoon (45\%), evening (44\%).

\section{Limitations}

The duration of the study was only two years, no data was available regarding out of hospital trauma, and road safety methods they have taken and the cases could not be followed up post operatively. The need for prospective studies to further support and validate the findings of the study.

\section{Conclusion}

Road traffic accidents are the most common cause of morbidity and mortality in young males, mostly occurring during night, and most of them sustained long bone fractures.

\footnotetext{
* Correspondence: sateeshkumarmuppasani@gmail.com

S.V.S. Medical College, Venugonda, Mahabubnagar, Andhra Pradesh, India
}

To minimise road traffic accident incidents avoid nighttime travelling.

Published: 25 July 2014

doi:10.1186/1865-1380-7-S1-P4

Cite this article as: Muppasani and Reddy: A two-year retrospective statistical analysis of trauma cases in our institute. International Journal of Emergency Medicine 2014 7(Suppl 1):P4.

\section{SpringerOpen ${ }^{\odot}$}

(C) 2014 Muppasani and Reddy; licensee Springer This is an Open Access article distributed under the terms of the Creative Commons Attribution License (http://creativecommons.org/licenses/by/2.0), which permits unrestricted use, distribution, and reproduction in any medium, provided the original work is properly credited.
Submit your manuscript to a SpringerOpen ${ }^{\circ}$ journal and benefit from:

- Convenient online submission

- Rigorous peer review

- Immediate publication on acceptance

- Open access: articles freely available online

- High visibility within the field

- Retaining the copyright to your article

Submit your next manuscript at $>$ springeropen.com 